\title{
ANTIMICROBIAL ACTIVITY IN LEAF EXTRACT OF NEEM IN BROILER
}

\author{
Rupaly Akhter ${ }^{1}$ and Md. Wadud Sarker ${ }^{2}$
}

${ }^{1}$ Department of Pharmacology and Toxicology, Faculty of Animal Science and Veterinary Medicine, Sher-e-Bangla Agricultural University, Dhaka-1207, Bangladesh; ${ }^{2}$ Department of Pharmacology, Faculty of Veterinary Science, Bangladesh Agricultural University, Mymensingh-2202, Bangladesh.

*Corresponding author: Rupaly Akhter; Email: rupaly_akhter@yahoo.com

\section{ARTICLE INFO A B S T R A C T}

Received

28 July, 2019

Revised

17 August, 2019

Accepted

28 August, 2019

Online

31 August, 2019

Key words

Azadirachta indica,

Escherichia coli

Salmonella

Zone of Inhibition
The main objective of the study was to evaluate antibacterial activity of Neem leaf extracts (methanolic) against $E$. coli and Salmonella using different test such as production performances, biochemical, hematological, bacteriological tests and zone of Inhibition (ZOI) method. Azadirachta indica (neem) leaf extract was used to test growth performance, biochemical, hematological parameters and antimicrobial activity against disease causing bacteria Escherichia coli and Salmonella. That's result indicated, methanolic extract of neem increased body weight, feed conversion ratio, decreased mortality rate from different microbial diseases.it also helped to maintain normal biochemical parameter for better health life of chicken. Neem extract increased leukocyte counts and decreased total viable count of bacteria in cecal faeces. Methanol extracts of varying concentrations 1.0, 1.5, 2.0 and $2.5 \%$ was prepared and tested against test organisms using agar diffusion method. Gentamicin of same varying concentrations was used to compare the effect of antimicrobial activity of methanol leaf extract. Data revealed that methanol extract of Neem has shown highest antimicrobial activity. Leaf extract of $A$. indica (Neem) had exhibited a potent antibacterial activity against various strain ( $E$. coli, Salmonella spp) of bacterial pathogens, it showed almost nearest to microbial activity of gentamycin.

To cite this article: Akhter R and MW Sarker, 2019. Antimicrobial activity in leaf extract of Neem in broiler. Res. Agric. Livest. Fish. 6 (2): 337-343.

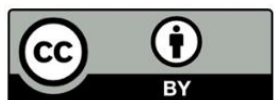

Copy right $\odot$ 2019. The Authors. Published by: AgroAid Foundation This is an open access article licensed under the terms of the Creative Commons Attribution 4.0 International License 


\section{INTRODUCTION}

The poultry production systems have led to marked increase in the production of poultry meat and eggs throughout the world (Armstrong, 1986). Many synthetic drugs and growth promoters are supplemented to the broilers to effect rapid growth, but their use have shown many disadvantages like high cost, adverse sideeffect on health of birds and long residual properties etc. European Commission banned four commonly used feed antibiotics: monensin sodium, salinomycin sodium, avilamycin, flavophospholipol. The banning of antibiotic growth promoter (AGP) will affect the poultry and livestock industry. To minimize the loss in growth, there is a need to find alternative to AGP. There are a number of non-therapeutic alternatives such as enzymes, inorganic acids, probiotics, prebiotics and herbs (Banerjee, 1998). Since ancient times herbs and their essentials have been known for their varying degree of antimicrobial activity (Juven et al., 1994). More recently, medicinal plants extracts were developed and proposed for use in food as natural antimicrobials (Hsieh and Mau 2001). Neem has attracted worldwide prominence due to its vast range of medicinal properties like antibacterial, antiviral, antifungal, antiprotozoal, hepatoprotective and various other properties without showing any adverse effects (Kale et al., 2003). Also, neem promotes growth and feed efficiency of birds because of their antibacterial properties (Prasannabalaji et al., 2012). Neem leaves extract has immunostimulant effect that activates the cell mediated immune response and therefore, creates an enhanced response to any future challenges occurred by disease organisms. So, the feeding neem leaves to immunosuppressed birds increased their humoral and cell mediate immune responses (Sadekar et al., 1998). Neem leaves contain a vast array of chemically diverse and biologically active ingredients (Devakumar and Suktt, 1993). Low dose of neem leave extract have an inhibitory action on wide spectrum of microorganisms (Talwar et al., 1997) and immuonomodulator actions that induce cellular immune reaction (Devakumar and Suktt, 1993). Administration of alcoholic extract of Neem flower disrupts the estrous cycle in Sprague Dawley rats and causes a partial block in ovulation and has the potential of an ideal antifertility agent (Gbotolorun et al., 2008). The great potential neem aqueous extract as powerful chemotherapeutic and antiviral agent (Hassan Amer et al., 2010). Considering the facts, the objectives of the present study was to evaluate the growth performance of broilers supplemented with neem leaf extracts and to determine the effect of neem leaves extracts in broiler diets as a possible alternative to antibiotic feed additives. In addition, the antimicrobial activity of neem leaves against pathogenic bacteria (Escherichia coli, Salmonella typhimurium etc.) was also investigated.

\section{METHODOLOGY}

\section{Preparation of leave extracts}

The leaves of neem (Azadirachta indica) were collected from Sher-e-Bangla Agricultural University (SAU), Dhaka-1207. The leave extracts was prepared with methanol. The obtained liquid extracts was subjected to Rotary evaporator and subsequently concentrate under reduced pressure (in vaccum at $40^{\circ} \mathrm{C}$ ) and evaporated to dryness and stored at $4^{\circ} \mathrm{C}$ in air tight bottle. $50 \mathrm{~g}$ of dry leaf powder were taken in a separate container. To this $250 \mathrm{ml}$ of methanol was added and kept for $24 \mathrm{~h}$ with periodic shaking then filtered and the filtrate was collected. The procedure was repeated three times with fresh volume of methanol. The filtrates were pooled. (Poonam Panchal et al, 2013).

\section{Experimental Design}

A total of 50 , day-old broiler chicks was purchased from Kazi hatchery and allowed acclimatizing for 3 days at the experimental shed. The initial body weights of assigned chickens were taken with digital weight machine and were recorded. The experiment was conducted according to the completely randomized design. Birds were divided into 5 equal groups $\left(T_{0}, T_{1}, T_{2}, T_{3}, T_{4}, T_{5} \& T_{6}\right)$. Group $T_{0}, T_{1}, T_{2}, T_{3}, T_{4}$ supplemented with neem at the dose rate of $1 \%, 1.5 \%, 2.0 \%, 2.5 \%$ of neem extract in drinking water and group $T_{5}$ treated with antibiotic, $\mathrm{T}_{6}$ group kept in control respectively in addition to commercial feed for 42 day of experiments. 


\section{Collection and Inoculum of Microorganism}

The Pathogenic strains of Escherichia coli and Salmonella typhimurium was used for this study. These strains were obtained from microbiology and Parasitology department in SAU. The microorganisms was inoculated in peptone medium and incubated at $37^{\circ} \mathrm{C}$ for $3-4$ hours and this was used as inoculums.

\section{Antimicrobial screening:}

Agar diffusion method was suitable for organisms that grower rapidly overnight at $35-37^{\circ} \mathrm{C}$ The well was made in medium after inoculation with microorganisms. When well was loaded with antibiotics, it diffuses in the medium and inhibits the growth of organism. There was logarithmic reduction in antibiotic concentration. The zone of inhibition of bacterial growth around each well was measured and the susceptibility is determined. Medium-Muller Hinton Agar $\left(3.8 \mathrm{gm} / 100 \mathrm{ml}\right.$ of distilled water) was prepared, autoclaved at $121^{0} \mathrm{c}$ for 15 minutes at $15 \mathrm{lbs}$ and poured in sterile petri plates up to a uniform thickness of approximately $5-6 \mathrm{~mm}$ and the agar was allowed to set at ambient temperature and used. $25 \mu \mathrm{l}$ of inoculum was spread over the MHA medium, using sterile spreader. After few minute, four wells were made in each Petri plate and loaded with 1.0, 1.5, 2.0 and 2.5\% methanol extract. Similarly 1.0, 1.5, 2.0 and 2.5\% gentamycin solution was added in another plate. Plates were incubated at $37{ }^{\circ} \mathrm{C}$ for $24 \mathrm{hrs}$. Antimicrobial activity was evaluated by measuring zone of inhibition by using Hi-media zone scale.

\section{Source of ration}

Readymade commercial broiler ration from renowned feed industry was used in experimental boilers.

\section{Study parameters}

The parameters was recorded weekly live weight, weekly feed consumption, FCR, mortality, DP, Hematological, biochemical parameter, total viable count of bacteria from caecal faces, in vitro activity of neem leaves in methanol extract against opportunistic pathogens.

\section{Statistical Analysis}

Data was analyzed in Randomized Completely Block Design (RCBD 1 factor). MSTAT-C computer package program (Russel, 2004) was used for data analysis. Statistically significant differences between group means were determined by analysis of variance (ANOVA). When the differences were significant, Duncan Multiple Comparison Range Tests (DMRT) was done at $5 \%$ level of significant. Excel Program was practiced for preliminary data calculation.

\section{RESULTS AND DISCUSSION}

Table 1 indicate production performances of broiler chicken, $\mathrm{T}_{1}$ (1\% Neem Leaf) that shows highest feed conversion compare to antibiotic groups $\left(T_{5}\right)$. Live weight is higher in treatment group $T_{2}(1.5 \%$ Neem Leaf) it is higher to antibiotic treated groups and low rate of neem extract is effective than higher percent of neem extract groups and antibiotic treated groups that $1 \%$ and $1.5 \%$ neem extract prevent mortality rate $(0 \%)$ in $\mathrm{T}_{1}$ and $\mathrm{T}_{2}$ whereas mortality rate $3.33 \%$ in gentamycin treated and $2 \%$ and $2.5 \%$ neem extract treated groups. It indicates daily production slightly higher or almost similar to gentamycin treated groups. That's result indicate that we can used neem extract alternative to antibiotic, it also helpful for chicken health, prevent side effect of antibiotics. 
Table 1. Production performance of broiler chicken treated with Neem and antibiotic

\begin{tabular}{llllll}
\hline Treatments & FC (g) & LW (g) & FCR & Mortality (\%) & DP (\%) \\
\hline T1(1.0\% Neem Leaf) & $2207^{\mathrm{A}}$ & $1697^{\mathrm{A}}$ & $1.29^{\mathrm{A}}$ & $0.00^{\mathrm{A}}$ & $72.41^{\mathrm{A}}$ \\
T2(1.5\% Neem Leaf) & $2217^{\mathrm{A}}$ & $1732^{\mathrm{A}}$ & $1.27^{\mathrm{A}}$ & $0.00^{\mathrm{A}}$ & $71.65^{\mathrm{A}}$ \\
T3(2.0\% Neem Leaf) & $2101^{\mathrm{B}}$ & $1708^{\mathrm{A}}$ & $1.23^{\mathrm{A}}$ & $3.33^{\mathrm{A}}$ & $70.42^{\mathrm{A}}$ \\
T4(2.5\% Neem Leaf) & $2104^{\mathrm{B}}$ & $1712^{\mathrm{A}}$ & $1.22^{\mathrm{A}}$ & $3.33^{\mathrm{A}}$ & $71.92^{\mathrm{A}}$ \\
T5(Gentamycin) & $2154^{\mathrm{AB}}$ & $1666^{\mathrm{A}}$ & $1.29^{\mathrm{A}}$ & $3.33^{\mathrm{A}}$ & $71.80^{\mathrm{A}}$ \\
T6(Control) & $2227^{\mathrm{A}}$ & $1718^{\mathrm{A}}$ & $1.29^{\mathrm{A}}$ & $3.33^{\mathrm{A}}$ & $72.29^{\mathrm{A}}$ \\
Mean \pm SE & $2168.33 \pm 29.49$ & $1705.33 \pm 19.27$ & $1.26 \pm 0.02$ & $2.22 \pm 2.50$ & $71.74 \pm 0.78$ \\
CV\% & 2.36 & 1.96 & 3.38 & 195.58 & 1.91 \\
LSD $(0.05)$ & 92.92 & $60.71^{\mathrm{NS}}$ & $0.08^{\mathrm{NS}}$ & $7.90^{\mathrm{NS}}$ & $2.48^{\mathrm{NS}}$ \\
\hline
\end{tabular}

Mean with different superscripts are significantly different $(P<0.05)$, Mean within same superscripts don't differ $(P>0.05)$ significantly, $\mathrm{SE}=$ Standard Error, $\mathrm{CV}=$ Coefficient of Variation, $\mathrm{LSD}=$ Least Significant Difference

Table 2. Some biochemical properties of broiler chicken treated with Neem and antibiotic

\begin{tabular}{|c|c|c|c|c|}
\hline Treatments & $\begin{array}{l}\text { Glucose } \\
\text { (mmol/L) }\end{array}$ & $\begin{array}{l}\text { Hemoglobin } \\
\text { (gm/dl) }\end{array}$ & $\begin{array}{l}\text { Cholesterol } \\
\text { (mg/dl) }\end{array}$ & $\begin{array}{l}\text { Uric Acid } \\
\text { (mg/dl) }\end{array}$ \\
\hline T1 (1.0\% Neem Leaf) & $\overline{10.55^{\mathrm{A}}}$ & $13.60^{\mathrm{B}}$ & $225^{\mathrm{A}}$ & $5.10^{\mathrm{AB}}$ \\
\hline T2 (1.5\% Neem Leaf) & $10.71^{\mathrm{A}}$ & $13.17^{\mathrm{B}}$ & $197^{\mathrm{A}}$ & $4.80^{\mathrm{B}}$ \\
\hline T3 (2.0\% Neem Leaf) & $10.33^{A}$ & $16.33^{\mathrm{A}}$ & $207^{A}$ & $5.03^{A B}$ \\
\hline T4 (2.5\% Neem Leaf) & $10.40^{\mathrm{A}}$ & $14.50^{\mathrm{B}}$ & $205^{\mathrm{A}}$ & $5.06^{\mathrm{AB}}$ \\
\hline T5(Gentamycin) & $10.83^{\mathrm{A}}$ & $14.23^{B}$ & $219^{A}$ & $5.70^{\mathrm{A}}$ \\
\hline T6(Control) & $11.50^{\mathrm{A}}$ & $13.17^{\mathrm{B}}$ & $219^{A}$ & $5.20^{\mathrm{AB}}$ \\
\hline Mean $\pm S E$ & $10.72 \pm 0.95$ & $14.16 \pm 0.50$ & $212.22 \pm 15.59$ & $5.15 \pm 0.23$ \\
\hline CV\% & 15.46 & 6.20 & 12.72 & 7.87 \\
\hline LSD (0.05) & $3.01^{\mathrm{NS}}$ & 1.59 & $49.12^{\mathrm{NS}}$ & 0.73 \\
\hline
\end{tabular}

Mean with different superscripts are significantly different $(P<0.05)$, Mean within same superscripts don't differ $(P>0.05)$ significantly, $\mathrm{SE}=$ Standard Error, $\mathrm{CV}=$ Coefficient of Variation, $\mathrm{LSD}=$ Least Significant Difference

Table 2 indicates biochemical properties of neem extracts, neem leaf extract treated group show lower glucose, cholesterol and uric acid level than antibiotic treated groups. That's means neem extract gives good biochemical parameter for healthy life of chicken. It also indicates higher hemoglobin level in neem leaf extract treated groups compare to gentamycin treated group. This data indicates we can give healthy life to broiler by treated with neem extract by avoiding antibiotic treatment. 
Table 3. Differential counts of Leukocytes of broiler chicken treated with Neem and antibiotic

\begin{tabular}{|lllll|}
\hline Treatments & Neutrophils (\%) & Lymphocytes (\%) & Monocytes (\%) & Eosinophils (\%) \\
\hline T1 (1.0\% Neem Leaf) & $29.00^{\mathrm{A}}$ & $58.33^{\mathrm{A}}$ & $8.33^{\mathrm{A}}$ & $4.33^{\mathrm{A}}$ \\
T2 (1.5\% Neem Leaf) & $31.67^{\mathrm{A}}$ & $56.33^{\mathrm{A}}$ & $8.33^{\mathrm{A}}$ & $3.66^{\mathrm{A}}$ \\
T3 (2.0\% Neem Leaf) & $33.67^{\mathrm{A}}$ & $56.67^{\mathrm{A}}$ & $7.33^{\mathrm{A}}$ & $2.33^{\mathrm{A}}$ \\
T4 (2.5\% Neem Leaf) & $28.67^{\mathrm{A}}$ & $59.67^{\mathrm{A}}$ & $8.00^{\mathrm{A}}$ & $3.66^{\mathrm{A}}$ \\
T5 (Gentamycin) & $29.33^{\mathrm{A}}$ & $62.00^{\mathrm{A}}$ & $6.66^{\mathrm{A}}$ & $2.00^{\mathrm{A}}$ \\
T6 (Control) & $32.00^{\mathrm{A}}$ & $58.67^{\mathrm{A}}$ & $7.33^{\mathrm{A}}$ & $2.00^{\mathrm{A}}$ \\
Mean \pm SE & $30.72 \pm 2.24$ & $58.61 \pm 1.81$ & $7.66 \pm 1.32$ & $3.00 \pm 0.73$ \\
CV\% & 12.63 & 5.37 & 30.03 & 43.60 \\
LSD $(0.05)$ & $7.05^{\mathrm{NS}}$ & $5.73^{\mathrm{NS}}$ & $4.18^{\mathrm{NS}}$ & $2.32^{\mathrm{NS}}$ \\
\hline
\end{tabular}

Mean with different superscripts are significantly different $(P<0.05)$, Mean within same superscripts don't differ $(P>0.05)$ significantly, $\mathrm{SE}=$ Standard Error, $\mathrm{CV}=$ Coefficient of Variation, $\mathrm{LSD}=$ Least Significant Difference

Table 3 shows data of hematological parameters. Total count of leukocyte is higher in treatment groups compare to gentamycin treated groups. That's results is neem leaf extract contain different antimicrobial properties.

Table 4. Total viable count of bacteria from caecal faeces of broiler chicken treated with Neem and antibiotic (Using dilution factor $10^{-4}$ )

\begin{tabular}{|ll|}
\hline Treatment & Colony forming unit of bacteria (cfu)/gram \\
\hline T1 (1.0\% Neem Leaf) & $40 \times 10^{4 \mathrm{~B}}$ \\
T2 (1.5\% Neem Leaf) & $20 \times 10^{4 \mathrm{~B}}$ \\
T3 (2.0\% Neem Leaf) & $23 \times 10^{4 \mathrm{~B}}$ \\
T4 (2.5\% Neem Leaf) & $44 \times 10^{4 \mathrm{~B}}$ \\
T5 (Gentamycin) & $33 \times 10^{4 \mathrm{~B}}$ \\
T6 (Control) & $163 \times 10^{4 \mathrm{~A}}$ \\
Mean \pm SE & $53.83 \times 10^{4} \pm 11.68 \times 10^{4}$ \\
CV\% & $37.58 \times 10^{4}$ \\
LSD $(0.05)$ & $36.81 \times 10^{4}$ \\
\hline
\end{tabular}

Mean with different superscripts are significantly different $(P<0.05)$, Mean within same superscripts don't differ $(P>0.05)$ significantly, $\mathrm{SE}=$ Standard Error, $\mathrm{CV}=$ Coefficient of Variation, $\mathrm{LSD}=$ Least Significant Difference

Table 4 showed data of total viable count of bacteria from caecal faeces of broiler chicken. Colony forming bacteria is lower in $\mathrm{T}_{2}$ \& $\mathrm{T}_{3}$ compare to antibiotic treated groups. That result indicates neem extract $1.5 \%$ and $2 \%$ showed highest antimicrobial activity than commercial treated antibiotics in broiler chick. 
Table 5. Antibacterial activity of methanol neem leaf extracts and gentamycin antibiotic against Salmonella and E. coli

\begin{tabular}{|c|c|c|c|c|c|c|c|}
\hline \multicolumn{2}{|c|}{ Concentration } & & \multirow{2}{*}{$\begin{array}{l}\begin{array}{l}\text { Zone of } \\
\text { inhibition }(\mathbf{c m})\end{array} \\
2.2 \\
\end{array}$} & \multirow{2}{*}{$\begin{array}{l}\text { Inhibition } \\
\text { Length }(\mathrm{cm})\end{array}$} & & \multirow{2}{*}{$\begin{array}{l}\begin{array}{l}\text { Zone of } \\
\text { inhibition }(\mathbf{c m})\end{array} \\
2.2\end{array}$} & \multirow{2}{*}{$\begin{array}{l}\begin{array}{l}\text { Inhibition } \\
\text { Length }(\mathrm{cm})\end{array} \\
1.5\end{array}$} \\
\hline Methanol & $1.0 \%$ & \multirow{8}{*}{ Salmonella } & & & \multirow{8}{*}{ E. coli } & & \\
\hline Neem & $1.5 \%$ & & 2.0 & 1.3 & & 2.4 & 1.6 \\
\hline \multirow[t]{2}{*}{ Extracts } & $2.0 \%$ & & 2.1 & 1.2 & & 2.1 & 1.3 \\
\hline & $2.5 \%$ & & 2.3 & 1.3 & & 2.2 & 1.2 \\
\hline Gentamycin & $1.0 \%$ & & 3.4 & 2.6 & & 2.7 & 2.1 \\
\hline \multirow[t]{3}{*}{ Antibiotics } & $1.5 \%$ & & 3.3 & 2.3 & & 2.5 & 1.5 \\
\hline & $2.0 \%$ & & 2.8 & 2.1 & & 2.6 & 2.0 \\
\hline & $2.5 \%$ & & 3.1 & 2.2 & & 2.4 & 1.9 \\
\hline
\end{tabular}

The results of $\mathrm{ZOI}$ of the plant extract and its comparison with standard antibiotic Gentamycin is recorded in Table 5. This results showed that the extract possessed antimicrobial activity against the tested organisms, depending upon the nature of the active ingredients present in the extracts and their capacity for diffusion into agar medium. ZOI activity of the methanolic extract of the Neem found to be significant activity against $E$. coli and salmonella respectively which has been shown in Table-5. Methanolic extract of neem showed an average inhibitory zone diameter $2.2 \mathrm{~cm}, 2.0 \mathrm{~cm}, 2.1 \mathrm{~cm}$ and $2.3 \mathrm{~cm}$ ) which indicates that methanolic extract gave best result having ZOI greater than that of standard antibiotic Gentamycin $(3.4,3.3,2.8$ and $3.1 \mathrm{~cm})$ against Salmonella bacteria while methanolic extract of Neem showed an average inhibitory zone diameter of $(2.2,2.4,2.1$ and $2.2 \mathrm{~cm})$ respectively which indicates that methanolic extract showed best result having ZOI greater than of the standard antibiotic Gentamycin $(2.7,2.5,2.6$ and $2.4 \mathrm{~cm}$ ) against $E$. coli. The methanol extract of $A$. indica against $E$. coli and Salmonella bacteria showed varieties zone of inhibition. Many of the existing synthetic drugs cause various side effects. Hence, drug development plant based compounds could be useful in meeting this demand for newer drugs with minimal side effects (Srivastava et al., 2000). Azadirachta indica leaves possessed good antibacterial activity, confirming the great potential of bioactive compounds and is useful for rationalizing the use of this plant in primary health care (Saradha jyothi, Subbarao, 2011). The extracts of Neem when used as medicinal plant, could be useful for the growth inhibition of the carcinogenic bacterium, S. sobrinus. (Md Mohashine Bhuiyan et al.,1997). The phytoconstituents alkaloids, glycosides, flavanoids and saponins are antibiotic principles of plants. These antibiotic principles are actually the defensive mechanism of the plants against different pathogens (Hafiza, 2000). The result is also supported by (Faiza aslamet al., 2009).

\section{ACKNOWLEDGEMENT}

We acknowledge the assistance and advice of Associate Prof. Md. Saiful Islam, Chairman, Dept. of Anatomy, Histology and Physiology, Sher-e-Bangla Agricultural University, for their kind co-operation. Thanks go to SAURES, Dhaka, Bangladesh who gives us funding for this work.

\section{REFERENCES}

1. Agarwal DP, 2002. Biological Activities and Medicinal Properties of Neem (Azadirachta indica): Current Science, 82(11): 1336-1345.

2. Akihisa T, T Noto, A Takahashi, Y Fujit and N Banno et al., 2009. Melanogenesis inhibitory, antiinflammatory and chemopreventive effects of limonoids from the seeds of Azadirachta indicia A. Juss. (Neem). Journal of Oleo Science, 58: 581-594. 
3. Armstrong DG, 1986. Gut active growth promoters. In: Control and manipulation of animal growth. Eds.By Buttery PJ, Lindsay DB and Haynes NB pp. 21-37.

4. Banerjee LK, 1998. Floral status of Buxa tiger reserve, West Bengal. Plant Diversity in the Tiger Reserves of India, 71.

5. Beuth J, H Schneider and $\mathrm{HL}$ Ko, 2006. Enhancement of immune responses to neem leaf extracts (Azadirachta indica) correlates with antineoplastic activity in BALB/c-mice. In Vivo, 20: 247-251. Bonsu FRK, JK Kagya-Agyemang, WKJ Kwenin and HK Zanu, 2012. Medicinal response of broiler chickens to diets containing neem (Azadirachta indica) leaf meal, haematology and meat sensory analysis. World Applied Sciences Journal, 19: 800-805.

6. Devakumar C and Suktt DV, 1993. Chemistry, In: Randhawa NS \& Parmar BS (eds), neem research and development. 63-96.

7. Faiza A, KU Rehman, M Asghar and M Sarwar, 2009. Antibacterial activity of various Phytoconstituents of Neem. Pakistan Journal of Agricultural Sciences, 46(3): 456-463

8. Gbotolorun SC, Osinubi AA, Noronha CC, Okanlawon AO, 2008. Antifertility potential of Neem flower extract on adult female Sprague Dawley rats. African Health Science, 8(3): 168-173.

9. Hafiza RE, 2000. Peptides antibiotics, Lancet, 349: 418422.

10. Hassan A, Wafaa A. Helmy, Hanan A.A Taie, 2010. invitro Antitumour activities of seeds and leaves Neem (Azadirachta indica) extracts. International journal of Academic Research, 2(2): 165-171.

11. Hsieh PC and Mau JL (2001). Antimicrobial effect of various combinations of plant extracts. Food Microbiology, 18: 35-43.

12. Juven BJ, Kanner J, Schved F and Weisslowicz H, 1994. Factors that interact with the antibacterial action of thyme essential oil and its active constituents. Journal of Applied Bacteriology, 76: 626-631.

13. Kale BP, Kothekar MA, Tayade HP, Jaju JB and Mateenuddin M, 2003. Effect of aqueous extract of Azadirachta indica leaves on hepatotoxicity induced by antitubercular drugs in rats. Indian Journal of Pharmacology, 35(3): 177-180.

14. Bhuiyan MM, Michiko N, Seishi M and T Shimono, 1997. Antibacterial effects of the crude Azadirachta indica Neem bark extract on Streptococcus sobrinus. Pediatric dental journal, 7(1): 61-64.

15. Nagalakshmi D, Sastry VRB, Katiyar RC, Agarwal DK, Verma SVS and Bisht, GS, 1998. Relative efficacy of alkali treated and urea ammoniation of neem (Azadirachta indica) seed kernel-cake on the performance of broilers. Indian Journal of Animal Science, 68: 961-964.

16. Poonam P, H Bajaj, S Maheshwari, 2013. Azadirachta indica (NEEM): antibacterial effects against Eschericha coli and Salmonella. Guru Drone Journal of Pharmacy and Research, 1(1): 18-21.

17. Prasannabalaji N, Muralitharan G, Sivanandan RN, Kumaran S and Pugazhvendan SR, 2012. Antibacterial activities of some Indian traditional plant extracts. Asian Pacific Journal of Tropical Disease, 2: S291-S295

18. Rakib MAA and MM Hussain, 2013. Assessment of cytotoxic effect of methanolic crude extracts of Azadirachta indica. International Journal of Pharmaceutical Sciences and Research, 4: 1585-1590.

19. Russel DF, 2004. MSTAT-C statistical software program. Director Plant and Soil Sciences Department, Michigan State University, USA.

20. Sadekar RD, Kolte AY, Barmase BS and Desai VF, 1998. Immunopotentiating effects of Azadiracta indica (Neem) dry leaves extract in broiler, naturally infected with IBD virus. Indian Journal of Experimental Biology 36(11): 1151-1153.

21. Saradhajyothi K and S Budida, 2011. Antimicrobial potential of the extracts of the leave of Azadirachta indica, Linn. Natural Science and Biology, 3(1): 65-69

22. Sharma GRK and Reddy YR, 2002. Neem (Azadirachta indica) and its Medicinal value in livestock production. Indian Journal of Arecanut Species and Medicinal Plants, 4: 56- 68

23. Srivastava A Shukla Kumar YN, 2000. Recent development in plant derived antimicrobial constituents. A Review. Journal of Medicinal and Aromatic Plant Science, 20: 717-72.

24. Talwar GPP, Raguvanshi RAS, Mukherjee and S Shah, 1997. Plant immunomodulators for termination of unwanted pregnancy and contraception and reproductive health. Immunology and Cell Biology, 75 (2): 190192. 